\title{
SEJARAH KONVERSI DARI ANIMISME KE AGAMA ISLAM SUKU ANAK DALAM DI KABUPATEN SAROLANGUN PROVINSI JAMBI (2005-2013)
}

\author{
Muhammad Ahat \\ STIT Kabupaten Tebo, mubmmadtahat@gmail.com
}

Arki Auliahadi

IAIN Bukittinggi, arkilpm@gmail.com

Diterima: 20 September $2018 \quad$ Direvisi: 13 November $2018 \quad$ Diterbitkan: 30 Desember 2018

\begin{abstract}
Bukit Duabelas is in the central part of Jambi Province between land transportation routes, namely between the central and eastern crossings of Sumatra, and the central crossing of Jambi. The position of Bukit Duabelas is also located among four sizable rivers, namely; Batang Hari River is in the north, Tabir River is in the west, Tembesi River is in the east and Merangin River is in the south. Ethnic, ethnic and religious cultures also influence communication styles, so culture can become an obstacle in integrating with one another, cultural barriers in integrating are caused by differences in norms and values shared by those involved in communicating. Suku Anak. Dalam is one of the Remote Indigenous Communities that inhabits the interior of Jambi Province, such as those in Merangin and Sarolangun Regencies. Since the last 8 years the Remote Indigenous Communities or better known as Suku Anak Dalam, have begun to experience social changes in the way they dress, education and religion. The Anak Dalam tribe has also begun to adapt to the outside community (Village People). Lately, many Anak Dalam tribes have gradually abandoned their ancestral beliefs and converted to Islam.
\end{abstract}

Keywords: History, Conversion, Suku Anak Dalam.

\begin{abstract}
Abstrak
Bukit Duabelas berada di bagian tengah Propinsi Jambi antara jalur-jalur perbubungan darat, yaitu antara lintas tengah dan timur Sumatera, serta lintas tengah Jambi. Posisi Bukit Duabelas juga berada diantara empat sungai yang cukup besar, yaitu; Sungai Batang Hari berada di bagian Utara, Sungai Tabir berada di bagian Barat, Sungai Tembesi berada di bagian Timur dan Sungai Merangin berada di bagian Selatan. Kebudayaan yang dimiliki oleh suku, etnis dan agama turut mempengarubi gaya komunikasi, sehingga budaya dapat menjadi sebuah rintangan dalam berintegrasi satu sama lain, rintangan budaya dalam berintegrasi ini disebabkan oleh perbedaan norma-norma dan nilai-nilai yang dianut oleb pibak yang terlibat dalam berkomunikasi. Suku Anak Dalam adalah salah satu Komunitas Adat Terpencil yang mendiami pedalaman Propinsi Jambi, seperti yang terdapat di Kabupaten Merangin dan Sarolangun. Semenjak 8 tahun terakbir Komunitas Adat Terpencil atau lebib dikenal dengan Suku Anak Dalam, sudah mulai mengalami perubahan sosial cara berpakaian, pendidikan dan agama. Suku Anak Dalam juga sudah mulai beradaptasi dengan masyarakat luar (Orang Desa). Akhir-akbir ini Suku Anak. Dalam sudah banyak yang berangsur meninggalkan keyakinan leluburnya dan memeluk agama Islam.
\end{abstract}

Kata Kunci: Sejarah, Konversi, Suku Anak Dalam 


\section{PENDAHULUAN}

Jambi adalah sebuah Propinsi yang kaya sumberdaya alam, mulai dari tanah yang subur bahkan masih terdapat hutan, semak belukar yang bisa dimanfaatkan oleh penduduk, untuk tempat bercocok tanam sebagai ladang dan lahan perkebunan. Propinsi Jambi terdapat berbagai suku bangsa antara lain Suku Weddoid, Suku Melayu, Suku Kerinci, Suku Bajau, Suku Orang Batin dan Suku Anak Dalam. Suku Anak Dalam dikategorikan sebagai komunitas terasing, mereka tersebar secara mengelompok di daerah pedalaman (hutan) pada beberapa kabupaten yang tergabung dalam wilayah Provinsi Jambi, yakni: Muaro Bungo, Tebo, Merangin, Sarolangun dan Batanghari. Ini artinya hanya Kotamadya Jambi, Kerinci, dan Tanjung Jabung yang bebas dari orang Suku Anak Dalam. Inilah yang menyebabkan apabila seseorang mendengar kata Suku Anak Dalam, maka yang ada dalam pikiran mereka adalah Jambi. ${ }^{1}$

Pada tanggal 23 Agustus 2000, sebagian wilayah yang dihuni oleh Suku Anak Dalam diresmikan sebagai Taman Nasional Bukit Duabelas (TNBD) oleh Menteri Kehutanan dan Perkebunan, di deklarasikan oleh Presiden RI Megawati Sukarno Putri pada tahun 2001 di Jambi. Taman Nasional Bukit Duabelas ini merupakan kawasan konservasi, secara keseluruhan luasnya 60,500 hektar, dengan rincian: 6.758 hektar ada di wilayah Kabupaten Sarolangun, 40.669 hektar ada di Kabupaten Batanghari, 12.483 hektar ada di Kabupaten Tebo (ada selisih 590 hektar dengan yang disebutkan dalam SK Menteri Kehutanan). Ini artinya, TNBD yang secara astronomis terletak di antara $1^{\circ} 45^{\mathrm{ee}}-1^{\circ} 58^{\mathrm{ee}}$ Lintang Selatan dan $102^{\circ} 32^{\mathrm{ee}}$ $102^{\circ} 59^{\text {ee }}$ Bujur Selatan ini, secara administratif termasuk dalam wilayah tiga Kabupaten. ${ }^{2}$

\footnotetext{
1 Melalatoa, J.. Ensiklopedi Sukubangsa di Indonesia. Jilid A-K (Jakarta: Departemen Pendidikan dan Kebudayaan, 1995), h. 34.

2 Dokumen, Kantor Taman Nasional Bukit Duabelas Kabupaten Sarolangun tahun 2013
}

Alam Taman Nasional Bukit Duabelas (TNBD) berupa dataran rendah, bergelombang (dengan kemiringan $2-40^{\circ}$ Celcius) dan perbukitan dengan ketinggian 50-438 meter dari permukaan air laut. Tinggi bukitnya kurang lebih 438 meter dari permukaan air laut, perbukitan itu sebagian besar diselimuti oleh hutan sekunder, bekas areal konsesi Hutan Produksi Hasil (HPH)selain terdapat di areal cagar biosfer Bukit Duabelas, di bagian utara dan sebelah timur cagar sebagian besar berstatus sebagai Hutan Produksi Terbatas (HPT). Hutan merupakan hutan tropis dataran rendah yang menjadi habitat satwa liar, seperti tapir (tapirus indicus), dan harimau Sumatera (panthera tigris sumatera). Jenis tanahnya didominasi oleh podsolik yang tidak terlalu subur dan mudah tererosi. ${ }^{3}$ Kebudayaan yang dimiliki oleh suku, etnis dan agama turut mempengaruhi gaya komunikasi, sehingga budaya dapat menjadi sebuah rintangan dalam berintegrasi satu sama lain, rintangan budaya dalam berintegrasi ini disebabkan oleh perbedaan norma-norma dan nilai-nilai yang dianut oleh pihak yang terlibat dalam berkomunikasi. ${ }^{4}$

Suku Anak Dalam di Taman Nasional Bukit Duabelas, Jambi mengikuti sekolah atau kelas jauh yang diselenggarakan organisasi pemerhati Suku Anak Dalam bersama pemerintah Kabupaten Sarolangun, Asisten Koordinator Proyek Bukit Duabelas. Komunitas Konservasi Indonesia (KKI) Warsi mengatakan, total Suku Anak Dalam di Taman Nasional Bukit Duabelas 1.689 orang dan 600 orang diantaranya adalah anak-anak. Sekitar350 orang di antara mereka sudah bisa membaca dan menulis melalui program kelas jauh. Proses pendekatan terhadap Suku Anak Dalam Jambi tergolong lama yakni sejak sepuluh tahun terakhir bahkan untuk mengajak Suku Anak Dalam belajar

3 http//www. Pemberdayaan Komunitas Adat Terpencil, Jambi.com, (23 Agustus 2000), diakses 4 Mei 2013, jam 22.30.Wib.

4 Hafied Cangara, Pengantar Ilmu Komunikasi, (Jakarta: PT Raja Grafindo Persada, 2003), h. 156. 
secara intensif baru bisadilakukan dalam waktu tiga tahun belakangan. ${ }^{5}$

Suku Anak dalam yang berada di Kabupaten Sarolangun terbagi kepada dua kelompok pertama Suku Anak Dalam yang menetap di pemukiman yang di sediakan oleh pemerintah atau instansi terkait, dibina dalam bidang pengembangan pertanian, perkebunan dan perternakan, kedua Suku Anak Dalam yang masih tinggal di Hutan yang hidup dengan cara berpindah-pindah dari satu tempat ketenpat yang lain, mereka didata sebaik mungkin untuk mengetahui berapa jumlah mereka yang sebenarnya. ${ }^{6}$ Penduduk Kabupaten Sarolangun mayoritas beragama Islam dan masih terdapat di daerah terpincil menganut kepercayaan tradisional seperti Suku Anak Dalam. Kepercayaan tradisional sering diakultrasikan dengan ajaran Agama Islam, ada sejumlah penganut yang memasukan kepercayaan nenek moyang. Misalnya masih terdapat berbagai suku yang sering disebut Komunitas Adat Terpencil atau lebih popular disebut Suku Anak Dalam. ${ }^{7}$

Melalui pengamatan dan penelusuran di berbagai daerah, Suku Anak Dalam yang berdomisili di Kabupaten Sarolangun mulai tertarik dengan hidup beragama, mereka sudah bisamembedakan antara yang baik dan yang tidak baik dalam menjalani kehidupan. Berdasarkan data sementara yang didapatkan oleh penulis di Kabupaten Merangin berjumlah sekitar 45 orang Suku Anak Dalam sudah memeluk agama Islam. ${ }^{8}$ Suku Anak Dalam yang berada di Kabupaten

2012

5 http// Surat Kabar, Kompas Jambi,Jumat 4 Mei

6 Al-Haris, Bupati Merangin, melalui sidang paripurna ulang tahun Kabupaten Merangin ke-49, di pola Kantor DPRD Kabupaten Merangi, Pidato, tanggal 8 Agustus 2014.

7 Budhi Vrihaspathi Jauhari, Arislan Said, Jejak Peradaban Suku Anak Dalam, (Bandung: Widya Padjajaran , 2012), h 23

${ }^{8}$ Dokumen, Kantor Kementrian Agama Kabupaten Merangin Tahun 2013.
Sarolangun, data yang didapatkan dari Kantor Kementerian Agama Sarolangun, warga Suku Anak Dalam yang memeluk agama Islam pada saat ini berjumlah sekitar 60 orang. ${ }^{9}$ Dengan demikian pada kedua Kabupaten tersebut telah terdapat 105 orang Suku Anak Dalam yang masuk Islam.

Ada sejumlah alasan mengapa pengkajian terhadap Suku Anak Dalam yang beragama Islam sangat penting, Dalam kehidupan Suku Anak Dalam ada tradisi atau budaya yang tidak sesuai dengan tuntutan ajaran Islam.Tradisi dan budaya Suku Anak Dalam tersebut seperti kebiasaan memakan babi, upacara adat dan pemujaan kepada roh nenek moyang. Sebagai sebuah tradisi yang dilakukan oleh mayoritas masyarakat non Muslim, hal tersebut jika bersinggungan dengan ajaran Islam, maka terjadi proses tawar-menawar dalam praktiknya. Dalam proses tawar-menawar ini, terjadi apa yang disebut Azyumardi Azra sebagai proses adhesi, ketimbang konversi. Dari hasil pengamatan sementara, memang terjadi proses adhesi, bagi Suku Anak Dalam yang konversi ke Agama Islam diberikan toleransi, kelenturan dalam pengamalan ajaran-ajaran Islam. ${ }^{10}$

\section{SUKU ANAK DALAM (SAD)}

Kehidupan Suku Anak Dalam di Jambi masih terikat kuat dengan adat istiadat dan ketergantungan pada hasil hutan, alam dan binatang buruan, Oleh sebab itu Suku Anak Dalam dikategorikan sebagai salah satu Komunitas Adat Terpencil (KAT) yang ada di Propinsi Jambi. Suku Anak Dalam juga disebut Kubu, Kubu dalam

9 Dokumen, Kantor Kementrian Agama Kabupaten Sarolangun Tahun 2013.melalui KasiPembinaan dan pengembanan Siear Islam. Drs.H. Suhaili.Mengatakan upaya yang sedang dilakukan oleh Kemenag Kabupaten Sarolangun dalam pemberdayaan terhadap Suku Anak Dalam yang telah masuk agama Islam adalah pengenalan tentang ajaran Islam secara menyeluruh melalui Penyuluh Agama Honorer.

10 Aswab Mahasin, dkk, (ed.), Rub Islam

dalam Budaya Bangsa: Aneka Budaya Nusantara,

(Jakarta: Yayasan Festival Istiqlal, 1996), h. 39. 
bahasa Melayu Jambi memiliki dua arti yaitu tempat persembunyian dan bodoh. Nama ini berasal dari desa yang bernama Kubu Kandang dan Pangabuan, yang berada di tepi sungai Batanghari. Kemungkinan desa tersebut merupakan perkampungan awal dari Suku Anak Dalam.

Mereka enggan disebut sebagai Orang Kubu, mereka lebih suka menyebut dirinya sebagai "Anak Dalam", "Orang Rimbo" atau "Orang Kelam". Sedangkan orang desa di sekitarnya disebut "Orang Terang". Ada tiga penyebutan terhadap Suku Anak Dalam, karena sebutan yang mengandung makna yang berbeda, yaitu:

1. Kubu merupakan sebutan yang paling populer digunakan terutama oleh orang Melayu dan masyarakat internasional. Kubu dalam bahasa Melayu memiliki makna peyorasi seperti primitif, bodoh, kafir, kotor dan menjijikan. Sebutan Kubu telah terlanjur populer terutama oleh berbagai tulisan pegawai kolonial dan etnografer pada awal abad ini.

2. Suku Anak Dalam istilah yang digunakan oleh pemerintah melalui Departemen Sosial dan sebutan yang digunakan oleh etnik ini untuk menyebut dirinya. Makna sebutan ini adalah menunjukkan jati diri mereka sebagai etnis yang mengembangkan kebudayaan tidak bisa lepas dari hutan. Anak Dalam memiliki makna orang terbelakang yang tinggal di pedalaman, karena itulah dalam perspektif pemerintah mereka harus dimodernisasikan dengan mengeluarkan mereka dari hutan dan dimukimkan melalui program pemberdayaan Komunitas Adat Terpencil.

3. Orang Rimba, Sebutan ini adalah yang paling proposional dan obyektif karena didasarkan kepada konsep Suku Anak Dalam itu sendiri. Asal usul penyebutan Orang Rimba pertama kali dipublikasikan oleh Moetholib Soetomo tahun 1995 dalam disertasinya yang berjudul 'Orang Rimbo: Kajian Struktural-Fungsional Masyarakat Terasing di Makekal, Propinsi Jambi.
Sejarah Suku Anak Dalam masih penuh misteri, bahkan hingga kini tidak ada yang bisa memastikan asal usul mereka. Hanya beberapa teori, dan cerita dari mulut ke mulut para keturunan yang bisa menguak sedikit sejarah mereka. Sejarah lisan Suku Anak Dalam selalu diturunkan para leluhur, seperti yang di ceritakan oleh Kitab (67), pemangku adat sekaligus warga tertua Suku Anak Dalam yang tinggal di Desa Mentawak Kecamatan Nalo Tantan Kabupaten Merangin Jambi dan Haji Jailani yang tinggal di Desa Bulit Suban Kecamatan air Hitam Kabupaten Sarolangun Jambi.

\section{KONVERSI AGAMA}

Konversi agama secara umum dapat diartikan dengan berubah agama ataupun masuk agama,konversi agama sebagai suatu macam pertumbuhan atau perkembangan spiritual yang mengandung perubahan arah yang cukup berarti dalam sikap terhadap ajaran dan tindakan agama, konversi agama menunjukkan bahwa suatu perubahan emosi yang tiba-tiba ke arah mendapat hidayah Allah SWT, secara mendadak telah terjadi yang mungkin saja sangat mendalam atau dangkal, mungkin pula terjadi perubahan tersebut secara berangsur-angsur. Dari definisi di atas dapat dibayangkan betapa sukarnya mengukur dan meneliti fakta konversi tersebut,samahalnya dengan fakta-fakta psikis lainnya, kita tidak dapat meneliti secara langsung proses terjadinya konversi tersebut, keadaan jiwa yang bagaimana memungkinkan terjadinya peralihan keyakinan secara mendadak itu. ${ }^{11}$ Bulliet menyatakan bahwa "Religius conversion is a difficult subject to studi". ${ }^{12}$ Mekipun demikian, tidak berarti konversi agama (masuk agama) suatu hal yang tidak mungkin untuk diteliti. Langkah awal yang dapat dilakukan dalam memahami konversi agama adalah menelusuri makna kata konversi itu

11 Zakiah Daradjat, Ilmu Jiwa Agama, Jakarta: Bulan Bintang, 2005, h.160

12 Richard W. Bulliet, Conversion to Islam and Emergence of Muslim Society in Iran"dalam Levtzon, Nehemia, h. 30 
sendiri, pengertian "masuk agama" bukan kata yang asing di kalangan masyarakat kita, Gambaran yang terbayang dari pengertian masuk agama adalah, seseorang sebelumnya masih menganut agama tradisi (animismeatau dinamisme), setelah konversi selanjutnya menganut agama Islam misalnya.

Proses terjadinya konversi agama antara seseorang dengan yang lainnya tidak selalu sama persis. Perbedaan ini terjadi disebabkan oleh latarbelakang dari individu itu sendiri berbeda,misalnya keadaan lingkungan, keadaan keluarga, dan keadaan pendidika.n

\section{SEBAB-SEBAB YANG MENDORONG UNTUK KONVERSI AGAMA. ${ }^{13}$}

Ada beberapa faktor yang tampaknya terjadi dan terdapat dalam setiap peristiwa konversi agama antara lain: Faktor Illahi, Faktor perkawinan, Faktor ekonomi, Faktor ajakan dari orang lain.

\section{Faktor Illabi (Hidayah)}

Konversi agama bagi Suku Anak Dalam merupakan suatu persoalan yang sering terjadi, seperti pada keluarga besar Haji Helmi, sebagian besar keluarga sudah berpindah agama, bahkan ada salah satu dari saudara Haji Helmi yang sudah bisa menghafal lima juz dari ayat al-Qu'an. Dalam pengakuan H. Helmi, bahwa asal-usul mereka adalah dari Datuk Mangku Muhammad yang beragama Islam, pada zaman penjajahan Belanda terpaksa melarikan diri untuk bisa bertahan hidup. Haji Helmi beserta keluarga melakukan konversi dari Animisme ke Agama Islam, kembali kepada agama Datuk (Datuk Mangku Muhammad), dalam penuturan yang disampaikan Haji Helmi, datuk Mangku Muhammad adalah pemeluk Agama Islam yang sangat panatik pada zamannya. ${ }^{14}$

13 Khusus poin D, Uka Tjandra Sasmita (ed,). Sejarah Nasional Indonesia III, (Jakarta, Grafitas, 1975), h.122

${ }^{14}$ H. Helmi, Tokoh masyarakat Suku Anak Dalam, di rumah kediaman H. Helmi, Desa Pematang Kabau, wawancara langsung, tanggal 09 Januari 2014
Dalam menjalani hidup di Bukit Duabelas Datuk Mangku Muhammad tidak menjalankan praktek ibadah Agama Islam, melainkan ikut kepada pengaruh Suku Anak Dalam yang ada dilingkungan Bukit Duabelas tersebut. Haji Helmi dan saudarasaudaranya kembali kepada jalan yang diridhoi Allah SWT, (ke Agama Islam), mereka pindah keyakinan dan menjalankan perintah Allah Swt, yang selama ini telah ditinggal oleh Datuk Mangku Muhammad.

Selain itu, Kepala Suku Anak Dalam Desa Pematang Kabau Kecamatan Air Hitam, Kabupaten Sarolangun, Jambi, Temenggung Tarib (Haji Jailani), memeluk agama Islam.bermula dari mimpi. Sekujur tubuhnya terbakar api. Saat minta pertolongan, tiba-tiba ada bisikan suara yang menyuruh mengucapkan Bismillah tujuh kali. Setelah mengikuti bisikan, api padam dan terlepas dari kobaran api yang membakar tubuhnya. Setelah mengucapkan dua kalimah sahadat, berganti nama Muhammad Jailani. Sedangkan istrinya yang semula bernama Hatijah Sanggul, setelah Islam menjadi Siti Hadijah. Penulis bertanya kepada Jailani, apa alasan mau masuk Islam, beliau menjawab, selama ini sudah meneliti semua agama, Islamlah agama yang memberi keselamatan. Haji Jailani juga menjelaskan tentang makanan didalam Islam ada yang halal dan haram, tetapi didalam kepercayaan kami hanya anjing yang tidak boleh dimakan, dalam agama yang selain Islam semuanya boleh dimakan. ${ }^{15}$

Ketika ditanya kepada istri Haji Jailani kenapa mau pindah ke Agama Islam, lantas ibu

15 Haji Jailani,Tokoh masyarakat Suku Anak Dalam, di rumah kediaman, Haji Jailani., Desa Bukit suban, wawancara langsung, tanggal 08 Januari 2014, Haji Jailani agak terlambat masuk Islam pada waktu itu, istrinya belum mau, setelah bermimpi haji jailani akhirnya membuat keputusan, bahwa ia akan masuk Islam dan pindah keluar (tidak dalam rimba lagi), sedangkan istrinya tetap di Rimba, Haji Jailani juga berjanji kepada istrinya tidak akan nikah lagi, semua harta kebun, uang direkening di serahkan kepada Istrinya, untuk napkah jailani juga berjanji akan member sampai salah satu dari keduanya sudah tiada. 
dengan enam orang anak tersebut menjawab, pada waktu diajak oleh bapak masuk Islam sebenarnya bukan tidak mau, akan tetapi belum mau pada waktu itu, tidak jauh dari Haji Jailani bermimpi saya juga bermimpi serupa dengan mimpi Haji Jailani.Pada suatu sore Haji Jailani diajak masuk Islam tanpa pikir panjang kedua suami istri menuju ke Desa Bukit Suban dan mengikrarkan dua kalimat syahadat di depan Imam Majid (Datuk Majid). ${ }^{16}$

Jika dianalisa dari faktor dari konversi agama Haji Jailani bersama Istri adalah melalui mimpi, akan tetapi untuk mengukur keabsahan mimpi tersebut sangan sulit sekali malah tidak bisa kita ukur dengan jenis alat apapun juga. Namun berdasarkan penuturan dari kedua suami istri maka mimpi mereka dapat kita simpulkan sebagai hidayah Allah SWT melalui mimpi. Sebelum memeluk Islam, Temenggung Tarib (Haji Jailani) menganut monotheis dalam bahasa Suku Anak Dalam disebut kepercayaan Behelo ${ }^{17}$ Sementara anaknya bernama Merekuh yang sudah berganti nama Yusup dan Mandun berganti nama menjadi Kadir, sudah duluan memeluk Islam.

Berdasarkan keterangan dari Haji Helmi dan Haji Jailani dan sumber yang penulis dapatkan, dari keseluruhan Suku Anak Dalam yang melakukan konversi agama di dua desa yaitu Desa Bukit Suban dan Pematang Kabau, kecamatan Air

16 Siti Khadijah, kediaman (rumah)di Desa Bukit Suban, wawancara langsung, tanggal , 8-01-2014, jam 09-30, wib, (Datuk Majid adalah imam Mesjid di desa Bukit Suban, jarak dari rumah kediaman Haji Jailani dan Siti khadijah kira-kira 200 meter.

17 Kepercayaan monoteisme adalah kepercayaan terhadap Tuhan Yang Maha Esa. Kepercayaan ini muncul berdasarkan pengalaman-pengalaman dari masyarakat. Melalui pengalaman itu, pola pikir manusia berkembang. Manusia mulai berfikir terhadap apa-apa yang dialaminya, kemudian mempertanyakan siapakah yang menghidupkan dan mematikan manusia, siapakah yang menghidupkan tumbuhtumbuhan, siapakah yang menciptakan binatang-binatang, bulan dan matahari. Pertanyaan-pertanyaan seperti ini terus dipikirkan oleh manusia, sehingga muncul suatu kesimpulan bahwa, di luar dirinya ada suatu kekuatan yang maha besar dan yang tidak tertandingi oleh kekuatan manusia. Kekuatan itu adalah kekuatan dari Tuhan Yang Maha Esa.
Hitam, Kabupaten Sarolangun,dapat penulis simpulkan bahwa sebgian besar mereka masuk Islam karena mendapat petunjuk dari Allah Swt.

\section{Faktor Perkawinan}

Faktor konversi agama yang sering terjadi la tarbelakang yang lebih umum adalah karena menikah dengan orang Islam, seperti Abdul Malik (masuk Islam Oktober 2005).

Abdul Malik menikah dengan seorang wanita Jawa, sebelumnya berkenalan dan menjalin hubungan pacaran. Dalam pergaulan sehari-hari sebelum masuk Islam Abdul Malik

berteman dengan orang-orang Islam dan sempat bermimpi membaca al-Quran. ${ }^{18}$ Hal yang senada juga disampaikan oleh Bahtiar, melakukan konversi agama hanya karena menikah dengan salah seorang gadis kampung, mereka sudah lama berkenalan, namun untuk melakukan pernikahan Bahtiar sebagai Suku Anak Dalam, mempunyai kepercayaan animisme harus konversi ke Islam terlebih dahulu. ${ }^{19}$

Bagi Suku Anak Dalam yang ingin menikah dengan orang Islam terlebih dahulu melakukan konversi agama dan belajar pengetahuan tentang agama Islam sebagai persyaratanuntuk menikah, jika dilakukan dengan baik maka pernikahan akan dilaksanakan. ${ }^{20}$ Setelah sekian lama menjalinkan hubungan sebagai status pacaran dengan seorang lelaki bersuku Jawa, akhirnya sepakat untuk melangsungkan kejenjang pernikahan, setelah sepakat dari semua pihak saya memutuskan untuk masuk Islam, pernikahan berlangsung dengan tata cara agama Islam. ${ }^{21}$

18 Abdul Malik, ketua RT 09 Desa Pematang Kabau, di rumah kediaman abdul Malik, Desa Pematang Kabau,Kecamatan air Hitam, wawancara langsung, tanggal 15 Januari 2014

19 Bahtiar, Desa Pematang Kabau,Kecamatan air Hitam, wawancara langsung, tanggal, 7 Januari 2014

20 Haji Helmi, Wawancara, dirumah RT 09 desa Pematang Kabau, tanggal 8 Januari 2014, jam 11.30 wib

21 Minah, , Desa Bukit Suban, wawancara langsung, tanggal 12 Januari 2014 
Dari 13 belas orang dari Suku Anak Dalam yang terdapat pada tabel di atas masing-masing mereka mengungkapkan bahwa konversi agama yang mereka lakukan erat hubungannya dengan perkawinan dengan orang Islam, faktor pernikahan atau faktor asmara, faktor ini terdiri dari 9 orang laki-laki dan 4 orang perempuan. Dua dari laki-laki menikah dengan orang Jawa dan tujuh orang dari laki-laki menikah dengan orang kampung, sedangkan yang perempuan tiga orang menikah dengan orang Jawa dan satu menikah dengan orang kampung, jika dibanding dengan faktor pertama maka faktor kedua ini kecil.

\section{Faktor Ekonomi}

Faktor yang ketiga ini adalah salah satu faktor yang sangat menjadi perdebatan dikalangan bagi yang melakukan konversi agama, dalam ungkapan-ungkapan Suku Anak Dalam, tidak tersirat bahwa masuk Islam karena menginginkan keuntungan ekonomis. Namun melihat faktor ekon omi lebih bersifat latarbelakang bersama yang akan dibahas lebih lanjut dalam bagian berikut.

Melihat kondisi hutan yang sudah semakin habis, dikonversi keberagam kepentingan, bisa jadi salah satu strategi adaptasi yang cukup rasional dikembangkan Suku Anak Dalam adalah dengan memeluk Agama Islam. Hal ini sesuai dengan pandangan konversi agama yang dilakukan oleh sebagian besar Suku Anak Dalam menurut pandangan penulis, bahwa keputusan Suku Anak Dalam untuk memeluk suatu agama merupakan sebuah kesadaran dan tahapan perkembangan dalam upaya agar mereka diterima oleh dunia luar, berkaitan dengan semakin berkurangnya hutan yang selama ini menjadi tempat hidup bagi Suku Anak Dalam. ${ }^{22}$

22 Abdul Malik, ketua RT 09 Desa Pematang Kabau, di rumah kediaman abdul Malik, Desa Pematang Kabau,Kecamatan air Hitam, wawancara langsung, tanggal 15 Januari 2014
Terkonversinya hutan menjadi wilayah transmigrasi, perkebunan, dan pertambangan, membuat mereka juga tidak bisa mempertahankan cara-cara lama dalam mempertahankan hidup.Pertanyaannya apakah cukup dengan hanya memeluk agama tertentu, lalu persoalan hidup terutama kesejahteraan sosial mereka dapat terselesaikan.Ketika hutan sebagai "rumah budaya" Suku Anak Dalam tidak mampu dilindungi keberadaannya oleh negara dan masyarakat, pilihan memeluk agama adalah pilihan yang rasional untuk dilakukan, karena hal ini dapat dilihat sebagai pintu masuk menuju perubahan yang direncanakan. Jika pilihan ini dilakukan, mereka harus mampu beradaptasi dengan kebudayaan Orang Dusun atau Melayu. Meninggalkan pola hidup yang lama, dan mengantinya dengan cara-cara orang Dusun. ${ }^{23}$

Untuk lebih menentukan secara tepat latarbelakang mereka melakukan konversi perlu digunakan teknik tersendiri yang peneliti maksud adalah dengan mengumpulkan sebanyak mungkin fenomena dan fakta yang diperoleh dari hasil wawancara maupun pengamatan langsung saat melakukan wawancara Pengamatan yang dilakukan memang terbatas pada apa yang terjadi sekarang akan tetapi tetap dapat ditelusuri keterkaitannya dengan masalalu, khususnya ketika terjadi proses konversi Beberapa fenomena dan fakta yang dikumpulkan akan menguji apakah dugaan awal tentang faktor ekonomi yang menjadi latarbelakang terjadinya konversi agama, atau ada faktor lain.

Jika memperhatikan beberapa fenomena diatas dikaitkan dengan kondisi kehidupan Suku Anak Dalam yang masih dalam kondisi ekonomi pas-pasan, maka sangat mungkin faktor ekonomis melatarbelakangi mereka masuk Islam. Jika menggunakan pendekatan psikologis, maka yang mendorong mereka melakukan konversi agama

23 Sulaiman, di rumah kediaman H. Jailani, Desa Bukit Suban, wawancara langsung, tanggal 12 Januari 2014 
adalah faktor eksternal, khususnya karena faktor kemiskinan. Karena miskin, maka membutuhkan kehidupan yang lebih baik. Keputusan untuk melakukan konversi agama dapat dikategorikan sebagai "tingkahlaku bermotivasi”yaitu "tingkah laku yang dilatarbelakangi oleh adanya kebutuhan dan diarahkan pada pencapaian suatu tujuan, agar suatu kebutuhan terpenuhi dan suatu kehendak terpuaskan. Masuk Islam dilatarbelakangi oleh adanya keinginan untuk memperbaiki taraf hidup kearah yang lebih baik secara ekonomis.

Di tengah pesatnya perkembangan dalam pembangunan pabrik dan lahan pertanian masyarakat sehingga Tempat berburu semakin sempit dan untuk mencari buah-buahan semakin susah, untuk memenuhi kebutuhan hidup bagi Suku Anak Dalam terasa mendapat tekanan dari berbagai pihak, karena semua kayu dan binatang yang terdapat dalam kawasan Taman Nasional Bukit Duabelas tidak boleh diambil, semua sudah dilindungi Negara. ${ }^{24}$

\section{Faktor Ajakan Dari Orang Lain (Sugesti)}

Faktor yang terakhir ini adalah faktor yang sangat berkaitan dengan tiga faktor yang terdahulu penulis jelaskan pada awal bab ini, melalaui penelusuran terhadap istri dan anak-anak dari Suku Anak Dalam apabila di tanya maka mereka menjawab konversi ke Islam adalah mengikuti orang tua dan suami, tidak peneliti temui setelah kepala keluarga memutuskan untuk masuk Islam sang istri dan anak menolak, melainkan ikut dengan untuk memeluk agama Islam. Setelah suami memutuskan untuk konversi ke Agama Islam, maka di ajak Masuk Islam, karena suami berharap supaya selalu bersama-sama mendapat kebaikan dunia dan

24 Saman, di rumah kediaman H. Jailani, Desa Bukit Suban, wawancara langsung, tanggal 11 Januari 2014, Jika ketahuan membunuh atau mengambil jenis tumbuhan yang terdapat dalam kawasan taman nasional, maka akan mendapat sangsi membayar denda atau di penjara akhirat, karena suami adalah pemimpin dalam rumah tangga, tidak mungkin suami mengajak anak dan istrinya ke jalan yang salah.Seorang istri harus patuh kepada suami. ${ }^{25}$

\section{PEMBINAAN SUKU ANAK DALAM}

Berdasarkan pantauan peneliti pada Suku Anak Dalam, yang tinggal di lingkungan RT 09 Desa Pematang Kabau, Suku Anak Dalam yang tinggal di sana sudah mengunakan pakaian seperti layaknya orang luar,walaupun seadanya dan seringkali dipakai hanya pada saat mereka mau ketempat orang banyak seperti kepasar dan masuk perkampungan, Suku Anak Dalamdiberikan pengertian, agama mengajarkan manusia untuk menutup aurat, pakaian juga memberi perlindungan pada tubuh, dari panas cuaca, sengatan hewan dan tumbuhan, Suku Anak Dalam sudahmengenal mandi dengan menggunakan sabun.

Penuturan Ibrahim setiap dua minggu satu kali Suku Anak Dalam diberi pengajian oleh Uztad yang datang dari Sarolangun, dibekali berbagai ilmu pengetahuan tentang agama, pada setiap Kamis malam Suku Anak Dalam dibimbing untuk membaca al-Qurean, bagi anak-anak diajari baca alQur'an setiap malam selasai shalat Maghrib, pada sore harinya diajari ilmu agama seperti shalat, puasa dan lain-lain. ${ }^{26}$

Perubahan nyata lainnya terlihat pada sudung, rumah mereka tinggal.Sebagai pengganti

${ }^{25}$ Ruqiah, Istri dari Rahman, RT 09, Desa Pematang Kabau, di Mushalla, Desa Pematang Kabau, Wawancaralangsung,

26 Ibrahim, guru mengaji di Mushalla RT 09, Desa Pematang Kabau, di Mushalla, Desa Pematang Kabau, Wawancaralangsung, tanggal 11-01-2014 jam 18.12 Wib.Ibrahim adalah salah seorang dari Suku anak Dalam yang pernah mendapat pendidikan pormal di pondok pesantren Darussalam selama lebih kurang tiga tahun, setelah itu Ibrahim melanjutkan pendidikan ke pondok pesantren Langitan Jawa Timur, ketika diwawancarai Ibrahim mengaku sudah hafal al-Quraean sebanyak 5 Juz. Sekarang Ibrahim diberi tugas untuk mengajar Suku Anak Dalam yang tinggal di komplek perumahan RT 09 Bukit Suban. 
rumbia, mereka menggunakan plastik untuk atap. Sekalipun demikian rumah mereka masih tak berdinding. Mereka masih menolak dimukimkan di luar hutan, mereka tetap memilih hidup di sudung. Sebagian dari Suku Anak Dalam ada yang memilih hidup tinggal di permukiman Sekalipun amat sederhana, rumah yang mereka diami jauh lebih layak daripada sudung. Disinilah Suku Anak Dalam melewatkan kehidupan sehari-hari. Masyarakat Suku Anak Dalam yang telah bersentuhan dengan dunia luar, mulai menjalani hidup sebagaimana masyarakat biasa. Mereka mulai mengenal nasi, yang dimasak dengan kayu bakar.Perlahan, mereka pun mulai diajarkan berladang. Walaupun berburu hewan belum sepenuhnya ditinggalkan, tapi bisa dibilang masyarakat Suku Anak Dalam berangsur tidak lagi mengandalkan hidup pada hasil hutan. Konsep pendidikan formal juga mulai diperkenalkan.Anak-anak Suku Anak Dalam sebagian belajar di sekolah Negeri. Jika jalan menuju sekolah banjir, mereka tetap berusaha belajar seadanya bersama para relawan dari KOPSAD. $^{27}$

Membina Suku Anak Dalam, sungguh bukan pekerjaan yang mudah. Suku Anak Dalam sebelumnya adalah manusia yang hidup dari alam. Hidup sekedar untuk bertahan hidup. tidak mengenal pakaian, rumah, apalagi sekolah. Tibatiba mereka diberi pilihan, untuk hidup sebagaimana layaknya, Pada dasarnya, masyarakat Suku Anak Dalam memiliki karakter yang amat tidak acuh dan tertutup.Sikap ini menyebabkan pendekatan kepada Suku Anak Dalam menjadi sulit terkadang serta merta menolak. Mengingat sulitnya pendekatan, setelah lima tahun upaya pemberdayaan Suku Anak Dalam, hasil yang dicapai, harus diakui belum maksimal. Dari sekitar empat ribu kepala keluarga, atau sekitar 17 ribu jiwa

27 KOPSAD, adalah LSM yang membantu warga Suku Anak Dalam bisa untuk berintragrasi dengan dunia luar
Suku Anak Dalam, yang tersebar di beberapa kabupaten di Jambi, baru sekitar 50 kepala keluarga yang telah bermukim secara tetap ${ }^{28}$

Usaha-usaha yang dilakukan oleh pemerintah daerah ataupun pusat terhadap Suku Anak Dalam adalah dengan cara memasyarakatkan dan membebas dari keterasingan atau isolasi. Mereka diberi tambahan pendidikan dan pengartahuan keterampilan pertanian, dalam kehidapan bermasyarakat ditanam nilai gotong-royong dan saling menghormati. Tetapi yang terpenting dari semua ini adalah pendidikan sekolah yang diselenggarakan oleh Departemen Sosial Pendidikan dan Kebudayaan. Bagi sebagian kelompok Suku Anak Dalam yang tidak mau dimukimkan dan dibina di tempat pemukiman, Suku Anak Dalam dibiarkan tinggal ditempat masing-masing tetapi oleh pemerintah secara administrasi diatur dan ditata kehidupannya sehingga merasakan adanya kekuasaan dan kewibawaan pemerintah. Secara langsung, Suku Anak Dalam menyadari bahwa mereka adalah juga bagian dari masyarakat dan penduduk Indonesia. ${ }^{29}$

Pembinaan terhadap suku Anak Dalam sebenarnya jauh dari Era Reformasi sudah mulai ada, akan tetapi untuk pembinaan tersebut sering terjadi kegagalan, oleh karena Suku Anak Dalam yang suka hidup dengan caranya sendiri. Suku Anak Dalam yang tinggal di Desa Bukit Suban dan Desa Pematang Kabau sangat merasakan fasilitas yang di bangun oleh pemerintah ataupun yang dibangun oleh lembaga-lembaga yang ikut dalam pembinaan, seperti LSM Kopsad Lsm KKI. ${ }^{30}$

28 ugeng, anggota LSM KOPSAD, di Kantor LSM KOPSAD Pematang Kandis Bangko, kecamatan Bangko, Kabupaten Merangin, wawancara Langsung, tanggal 17 Desember 2013

29 Mujito, Sekretaris Desa dan Pembina Suku Anak Dalam diwilayah Desa Bukit Subandi rumah kediaman Mujito, Desa Pematang Kabau,Kecamatan Air Hitam, W awancara langsung, tanggal, 7 Januari 2014

30 Sugeng, anggota LSM KOPSAD, di Kantor LSM KOPSAD Pematang Kandis Bangko, kecamatan Bangko, 
Kegiatan-kegiatan pemerintah setempat telah menyebabkan Suku Anak Dalam juga menjadi terbuka pikirannya mengenai politik. Dalam kegiatan-kegiatan penerangan politik dan pemilihan umum. Suku Anak Dalam sudah ikut andil dalam pesta demokrasi tersebut, dengan demikian Suku Anak Dalam pada masa sekarang ini tidak lagi terisolasi dari masyarakat luas, tetapi secara sosial dan ekonomi masih berada dalam keadaan keterbelakangan atau terasing.

\section{Bidang Sosial}

Masyarakat Suku Anak Dalam yang bermukim di Desa Bukit Suban dan Pematang kabau telah mengalami pergeseran sosial budaya. Pergeseran budaya masyarakat Suku Anak Dalam, jika dilihat dari segi generasi dapat dapat diklasifikasikan menjadi tiga ketagori.

1. Genarasi tua sebagian besar masih memegang teguh adat istiadat yang berlaku.

2. Genarasi dewasa sudah ada yang meninggalkan kebiasaan kebiasaan di masyarakat.

3. Generasi muda sebagian besar sudah meninggalkan kebiasaan atau adat-istadat mereka.

Perubahan atau pergeseran sosial pada generasi muda lebih banyak mengarah kepada perubahan yang negatif. Mereka sudah ada yang mengenal disko, mengenal minum-muniman yang memabukan, main kartu dan juga ada yang sudah mengenal wanita nakal.

\section{Bidang Ekonomi}

Upaya untuk menciptakan alternativ tambahan penghasilan bagi komunitas Suku Anak Dalam yang tinggal di jalur lintas tengah Sumatera terus dijajaki oleh SSS Pundi (PT. Sawit), melalui rekan-rekan pendamping di lapangan. Penjajakan ini tentunya didasari oleh potensi di lapangan,

Kabupaten Merangin, wawancara Langsung, tanggal 17 Desember 2013 pengalaman yang memang sudah ada serta keinginan dari komunitas Suku Anak Dalam sendiri. Keputusan untuk satu pilihan kegiatan yang didukung oleh SSS Pundi melalui support program PNPM Peduli itu pun bukan semata-mata atas keinginan dan persetujuan dari ketua rombong saja. Melainkan harus sepengetahuan dan persetujuan dari semua anggota rombong.

Pilihan kegiatan yang dapat menambah pendapatan bagi Mansyur dan anggota rombongnya kegiatan berternak kambing. Hingga akhirnya program ini memfasilitasi penyediaan bahan untuk pembuatan kandang serta pembelian kambing 24 ekor yang dibagikan secara merata untuk semua anggota rombong. ${ }^{31}$

Kemauan lain yang dapat dilihat dari pergeseran atau perubahan ekonomi masyarakat Suku Anak Dalam adalah kepemilikan atas barangbarang perlengkapan kebutuhan hidup sehari-hari. Mereka sebagian sudah ada yang memiliki alat-alat informasi seperti radio dan televisi, alat transpormasi seperti kendaraan roda dua, bahkan ada yang memiliki kendaraan roda empat. Perhiasan berharga seperti cincin, kalung, gelang dan jam tangan juga sudah mereka punyai.

\section{Bidang Kesehatan}

Dalam pelayanan kesehatan terhadap Suku Anak Dalam pemerintah sudah mulai memperhatikan meskipun belum begitu memuaskan tetapi saat peneliti bertanya kepada salah satu warga RT 09 Desa Pematang Kabau. Untuk pelayanan kesehatan sudah cukup baik, Suku Anak Dalam sudah dapat berobat gratis ke Puskesmas yang ada di Desa, seandainya penyakit sudah tidak bisa di obat di Puskesmas maka mereka di antar untuk berobat ke Bangko atau Sarolangun,

31 Mansur, Ketua rombong peternak kambing,Desa Pematang Kabau, di rumah kediaman Kepala Desa Pematang Kabau, Wawancaralangsung, tanggal 7 Januari 2014 
sering juga mereka di antar ke Jambi untuk berobat. $^{32}$

\section{Kesenian dan Keraïnan}

Dalam pembinaan keterampilan Tim mengubah metode pembinaan dengan door to door yaitu mendatangi langsung ke rumah-rumah warga Suku Anak Dalam dan kemudian melakukan pembinaan. Tim membiarkan Suku Anak Dalam membuat sesuatu yang mereka bisa.Tim membina dan mengarahkan Suku Anak Dalam sedangkan dalam hal ukuran benda yang ideal, kerapian, pengawetan, serta membantu mencari dan memilih beberapa bahan alam pendukung modifikasi.

\section{Bidang Pendidikan}

Suku Anak Dalam akhir-akhir inimulai mendapatkan pendidikan formal ataupun non formal, sebagai mana yang dilakukan oleh Rini, mengajar Suku Anak Dalam di pedalaman hutan di Jambi. Memang tidak mudah, mereka tidak bisa berbahasa Indonesia, suka bertindak, tidak memerhatikan kebersihan. Namun Tri Rini Widiyastuti, perempuan asal Yogyakarta yang bertransmigrasi ke Jambi, ikhlas mengabdikan diri sebagai guru Suku Anak Dalam di sekolah Alam Putri Tijah Dusun Kutai, Desa Pematang Kabau, Kecamatan Air Hitam Kabupaten Sarolangun, Provinsi Jambi. ${ }^{33}$

Suku Anak Dalam sekarang mereka tidak mau lagi ketinggalan dalam mencari ilmu pendidikan sesuai dengan pengembangan dan pembinaan yang dilakukan baik dari pemerintah setempat atau pun dari istansi-istansi yang ikut berperan dalam pembinaan.

${ }^{32}$ Nursidah, Wawancara, di rumah ketua RT 09 Desa Pematang Kabau, tanggal 8 januari

2014, jam 19-30 Wib

33 Tri Rini Widiyastuti, Kepala Sekolah Alom, dirumah kediaman, diDesa Pematang Kabau, Ujung Kutai, Wawancara langsung, tanggal 8 januari 2014, jam 11-00 Wib.
Bidang Keagamaan

Suku Anak Dalam yang telah masuk Islam mempunya keyakinan seperti orang muslim pada secara umum, bahwa tuhan yang menciptakan alam semesta adalah zat yang mempunyai kekuasaan di alam raya ini. Mereka menyerahkan semua urusan hanya kepada Allah SWT, menurut sumber bahwa Islam merupakan agama yang jelas segala aturan dan sangat berbeda dengan agama yamg lain, sebagai contohnya Islam meminta kepada pemeluknya menjaga kesucian, melarang kekerasan seperti berkelahi dan makan minum yang kotor. ${ }^{34}$

Kondisi masjid memang masih jauh dari sempurna sebab masih terkendala dana penyelesaian, karena itu mengharapkan agar ada bantuan dari pemerintah supaya tempat ibadah masyarakatam Suku Anak Dalam bisanyaman digunakan. Suku Anak Dalam sangat berharap agar masjid ini bisa cepat selesai.Sehari-harinya, warga aktif menggunakan masjid guna kegiatan ibadah seperti shalat berjamaah, pengajian ibu-ibu, anakanak dan kegiatan Agama Islam lainnya.

\section{DAFTAR KEPUSTAKAAN}

Melalatoa, J.. Ensiklopedi Sukubangsa di Indonesia. Jilid A-K (Jakarta: Departemen Pendidikan dan Kebudayaan, 1995), h. 34.

Dokumen, Kantor Taman Nasional Bukit Duabelas Kabupaten Sarolangun tahun 2013

http//www. Pemberdayaan Komunitas Adat Terpencil, Jambi.com, (23 Agustus 2000), diakses 4 Mei 2013, jam 22.30.Wib.

Hafied Cangara, Pengantar Ilmu Komunikasi, (Jakarta: PT Raja Grafindo Persada, 2003), h. 156.

34 Wahab, Wawancara, saat di temui diMTs Nurul Huda, tanggal, 6 Januari 2014, jam 11,00 wib, wahab adalah orang kampung yang berstatus pengasuh anak-anak Suku Anak Dalam. Pada saat ditanya wahab mengeluh dalam kondisi keluarga yang pas-pasan beliua mengasuh 6 orang anak, Suku Anak Dalam. Harapan dari wahab adalah supaya dapat membuat sedikit rumahnya kesamping sekedar untuk tempat buat tempat tidur untuk anak-anak 
http// Surat Kabar, Kompas Jambi,Jumat 4 Mei 2012 Al-Haris, Bupati Merangin, melalui sidang paripurna ulang tahun Kabupaten Merangin ke-49, di pola Kantor DPRD Kabupaten Merangi, Pidato, tanggal 8 Agustus 2014.

Budhi Vrihaspathi Jauhari, Arislan Said, Jejak Peradaban Suku Anak Dalam, (Bandung: Widya Padjajaran , 2012), h 23

Dokumen, Kantor Kementrian Agama Kabupaten Merangin Tahun 2013.

Dokumen, Kantor Kementrian Agama Kabupaten Sarolangun Tahun 2013.melalui KasiPembinaan dan pengembanan Siear Islam. Drs.H. Suhaili.Mengatakan upaya yang sedang dilakukan oleh Kemenag Kabupaten Sarolangun dalam pemberdayaan terhadap Suku Anak Dalam yang telah masuk agama Islam adalah pengenalan tentang ajaran Islam secara menyeluruh melalui Penyuluh Agama Honorer.

Aswab Mahasin, dkk, (ed.), Rub Islam dalam Budaya Bangsa: Aneka Budaya Nusantara, (Jakarta: Yayasan Festival Istiqlal, 1996), h. 39.

Zakiah Daradjat, Ilmu Jiwa Agama, Jakarta: Bulan Bintang, 2005, h.160

Richard W. Bulliet, Conversion to Islam and Emergence of Muslim Society in Iran"dalam Levtzon, Nehemia, h. 30

Uka Tjandra Sasmita (ed,). Sejarah Nasional Indonesia III, (Jakarta, Grafitas, 1975), h.122 